\title{
Self-Care Pattern among Mature Woman with Hypertension at Karyawangi Village of Parongpong District of Bandung Regency: A Phenomenological Study
}

\author{
Imanuella and Samuel M. Simanjuntak \\ Universitas Advent Indonesia
}

\begin{abstract}
Hypertension, known as the silent killer, is a condition where the systolic blood pressure is more than $120 \mathrm{mmHg}$ and diastolic pressure is more than $80 \mathrm{mmHg}$. The study explored the patient's self-care patterns toward the hypertension, environmental patterns, family roles, coping method, and how to obtain health assistance. This study made use of qualitative-phenomenological methods of research by conducting an indepth interview on seven respondents utilizing ten semi-structured questions. The participants were selected using the purposive sampling with inclusion and exclusion criteria. The following themes were identified after the conduct of the study: selfphysical, emotional condition, cognator, mastery experience, vicarious experience, self-concept, self-efficacy, persuasion, regulator and interdependence. The study also recommended that other characteristics from each category be explored such as patient self-care patterns and lifestyle patterns. It also recommended that the health officer provide clear information that is easy to understand. Furthermore, regular health education must be provided among mature woman.
\end{abstract}

Keywords: hypertension, self-Care, adaptation, self-efficacy, community 